\title{
Analisa Penerapan Prinsip Syariah dalam Asuransi
}

\author{
Teguh Suripto, Abdullah Salam \\ Program Studi Perbankan Syariah \\ Universitas Alma Ata \\ Jalan Brawijaya no.99, Yogyakarta 55183 \\ email: teguh_suripto@yahoo.com
}

\begin{abstract}
In recent years, we have heard and seen many economic activities based on Islamic law or Sharia law. These activities are related to the production process in the service industry. So it appears Sharia Business Unit (UUS), such as Islamic Banking, Sharia Insurance, Sharia Pawnshops, Sharia Leasing, even up to syariah tourism. This is certainly very reasonable, because the rationality and social level of human life undergo many changes, from the level of social and economic life that has freedom, to a new economic level that requires religious values. The Islamic economic system has different characteristics from conventional economics. Islamic economics is a fair and thorough system and seeks to ensure that wealth is not collected only to one group, but spread throughout society. (Afzalur Rahman, 1996: 11). One of Sharia financial institutions that can apply the sharia principles is Sharia Insurance. This research will try to analyze the principles of sharia in insurance, using qualitative descriptive method that is describing the object of research by using literature study that comes from the relevant book or journal. The result of the research shows that there are 8 principles in Takaful Insurance which become the guideline of implementation, that is Tawheed (Ketaqwaan), Justice, Not Dzalim, At Tawaun (please help), Amanah, Ridha, Khitmah (good service), and free from gharar element, maisir, and usury. In practice many sharia entities have been implementing sharia principles well although there are still some shortcomings in Takaful insurance, for example in research that has been done by Erza Armas hardi, 2015 obtained the result that Takaful insurance has not touched the bottom of society group (grass root).
\end{abstract}

Keywords: sharia insurance, sharia principles, sharia entity, tabarru

\section{ABSTRAK}

Beberapa tahun belakangan ini, kita mendengar dan melihat banyak aktivitas ekonomi berlandaskan hukum Islam atau Syariah Islam. Aktivitas tersebut berhubungan dengan proses produksi di industri jasa. Sehingga muncul Unit usaha Syariah (UUS), seperti Perbankan Syariah, Asuransi syariah, Pegadaian Syariah, Leasing Syariah, bahkan sampai dengan pariwisata syariah. Hal ini tentu sangat wajar, karena rasionalitas dan tataran sosial kehidupan manusia mengalami banyak perubahan, dari tataran kehidupan sosial dan ekonomi yang memiliki kebebasan, sampai dengan tataran ekonomi baru yang memerlukan nilai-nilai religius. Sistem Ekonomi Islam memiliki karakteristik yang berbeda dengan ekonomi konvensional. Ekonomi Islam merupakan sistem yang adil dan seksama serta berupaya menjamin kekayaan tidak terkumpul hanya kepada satu kelompok saja, tetapi tersebar ke seluruh masyarakat. (Afzalur Rahman, 1996 : 11). Salah satu lembaga keuangan Syariah yang dapat menerapkan prinsip syariah tersebut adalah Asuransi Syariah.Penelitian ini akan mencoba menganalisa prinsip - prinsip syariah di dalam asuransi, dengan menggunakan metode diskriptif kualitatif yaitu menggambarkan obyek penelitian dengan menggunakan studi literatur yang berasal dari buku maupun jurnal yang relevan. Hasil penelitian menunjukkan bahwa terdapat 8 prinsip dalam asuransi syariah yang menjadi pedoman pelaksanaannya, yaitu Tauhid ( Ketaqwaan ), Keadilan, Tidak Dzalim, At Tawaun (tolong menolong), Amanah, Ridha, Khitmah (pelayanan yang baik), dan terbebas dari unsur gharar, maisir, dan riba. Dalam pelaksanaannya banyak entitas asuransi syariah telah menjalankan prinsip syariah dengan baik walaupun masih terdapat beberapa kekurangan dalam asuransi 
syariah, misalnya dalam penelitian yang telah dilakukan oleh Erza Armas hardi, 2015 diperoleh hasil bahwa asuransi syariah belum menyentuh kelompok masyarakat paling bawah (grass root).

Kata Kunci : asuransi syariah, prinsip-prinsip syariah, entitas syariah, tabarru

\section{PENDAHULUAN}

Beberapa tahun belakangan ini, kita mendengar dan melihat banyak aktivitas ekonomi berlandaskan hukum Islam atau Syariah Islam. Aktivitas tersebut berhubungan dengan proses produksi di industri jasa. Sehingga muncul Unit usaha Syariah (UUS), seperti Perbankan Syariah, Asuransi syariah, Pegadaian Syariah, Leasing Syariah, bahkan sampai dengan pariwisata syariah. Hal ini tentu sangat wajar, karena rasionalitas dan tataran sosial kehidupan manusia mengalami banyak perubahan, dari tataran kehidupan sosial dan ekonomi yang memiliki kebebasan, sampai dengan tataran ekonomi baru yang memerlukan nilai-nilai religius.

Perkembangan sistem ekonomi konvensional diawali dengan terbitnya buku "An Incuiry into the nature and causes of the wealth of nation" oleh Adam Smith pada tahun 1776-an. yang merupakan guru besar dari Glasgow, ini merupakan cikal bakal yang kemudian disebut sebagai mazhab klasik atau mazhab liberal (Kaslan, 1975 :25, dalam Erza Armas : 2015). Inilah era tatanan kehidupan ekonomi dan sosial yang memberikan kebebasan sepenuhnya kepada para pelaku pasar untuk melakukan transaksi, aktivitas transaksi tersebut ditentukan sepenuhnya oleh mekanisme pasar. Lebih kurang 160 tahun kemudian atau satu setengah abad lebih mazhab ini dirasa tidak lagi dapat mengakomodir berbagai permasalahan negara penganutnya.(Erza Armas, 2015). Setelah berkurangnya pengaruh mazab tersebut, sekitar tahun 1970 para ahli ekonomi dari negara-negara muslim dari jedah sampai dengan Arab saudi mengadakan pertemuan. Pertemuan tersebut membahas bagaimana aktivitas ekonomi dapat berjalan sesuai dengan ajaran Islam.

Sistem Ekonomi Islam memiliki karakteristik yang berbeda dengan ekonomi konvensional. Ekonomi Islam merupakan sistem yang adil dan seksama serta berupaya menjamin kekayaan tidak terkumpul hanya kepada satu kelompok saja, tetapi tersebar ke seluruh masyarakat. (Afzalur Rahman, 1996 : 11). Ciri penting sistim ekonomi Islam tersebut digambarkan dalam ayat Al Qur'an, yang artinya "Supaya harta itu jangan hanya beredar di antara golongan kaya saja di kalangan kamu" (Al Hasyr : 7). Dengan berkembangnya Ekonomi Islam, maka aktivitas ekonomi semakin seimbang. Dalam teorisasi ekonomi konvensional, tujuan utama aktivitas ekonomi hanya untuk kepentingan duniawi tanpa memandang kepentingan ilahi. Sedangkan dalam teorisasi Ekonomi Islam segala aktivitas ekonomi harus memiliki tujuan yang seimbang yaitu antara duniawi dan kepentingan ilahi. Dalam pandangan Islam, aktivitas ekonomi harus memperhatikan keseimbangan yang sesungguhnya antara tujuan - tujuan material (kebendaan) dengan nilai- nilai spiritual (kerohanian) yang sangat mutlak untuk kejayaan hidup didunia. Al Qur'an memerintahkan umat manusia agar memohon kepada Allah supaya memberi petunjuk kearah hidup yang seimbang. (Afzalur Rahman, 1995 : 26).

Dengan ajaran yang seimbang tersebut, maka Islam menganjurkan bahwa setiap kegiatan investasi harus memperhatikan prinsip-prinsip yang ada didalam agama Islam. Salah satu kegiatan investasi yang harus memperhatikan nilai-nilai Islam tersebut adalah Asuransi. Didalam asuransi yang diinvestasikan adalah jaminan yang diberikan penanggung (perusahaan asuransi) kepada yang tertanggung untuk resiko kerugian yang telah ditetapkan di dalam perjanjian (polis) bila terjadi kebakaran, sakit, kecurian, kerusakan atau kehilangan jiwa, dengan kewajiban tertanggung membayar premi setiap bulannya. Asuransi pada awalnya berkembang dengan sistem konvensional, namun demikian sampai dengan saat ini telah berkembang menjadi asuransi syariah. Salah satu dari banyak lembaga keuangan non-bank pada sektor 
syariah adalah asuransi yang disebut juga dengan takaful, model akad yang digunakan bisa dengan bentuk tijarah dan bisa juga dengan bentuk tabarru (Haykal, 2010 : 181).

Menurut laporan tahunan Bappepam-LK menyebutkan bahwa pertumbuhan industri asuransi syariah cukup baik pada tahun 2011. Pertumbuhan industri ini ditunjukan oleh meningkatnya jumlah kekayaan dan dana invenstasi yang dimiliki industri perasuransian syariah sebesar Rp9,2 Triliun dan Rp7,8 Triliun (dilihat dari data yang belum dilakukan audit). Dari angka tersebut, pertumbuhan yang terjadi pada industri ini sebesar 31,94\% dan $33,76 \%$. Adapun dana bruto yang diperoleh dari iuran tabarru, ujrah yang diterima perusahaan dan jumlah kontribusi investasi pada tahun 2011 mencapai Rp4,7 Triliun atau mengalami kenaikan sebesar 34,89\% dari tahun sebelumnya.(Eja Armaz Hardi, 2015 : 424 - 425 ). Sedangkan pada tahun 2017 Berdasarkan ikhtisar data keuangan asuransi syariah per Juli 2017 yang dirilis oleh Otoritas Jasa Keuangan (OJK), aset industri asuransi syariah mencapai Rp37,293 triliun. Jumlah tersebut naik 17,26\% bila dibandingkan dengan periode yang sama tahun sebelumnya, yaitu Rp31,802 triliun. Sementara itu Asosiasi Asuransi Syariah Indonesia (AASI) mencatat, kontribusi bruto industri asuransi syariah per semester I 2017 tumbuh 3,46 persen dibandingkan periode sama tahun lalu (yoy). Nominal kontribusi sebesar Rp 6,16 triliun.

Dengan melihat realitas perkembangan asuransi syariah tersebut, muncul optimisme bahwa asuransi syariah dapat berkembang dengan pesat di Indonesia, apalagi hampir 80 $\%$ penduduk indonesia adalah muslim. Namun demikian masih muncul perdebatan dalam pelaksanaan asuransi syariah. Perdebatan tersebut menyangkut pelaksanaan prinsip syariah dalam asuransi, tata kelola asuransi syariah, permodalan asuransi syariah, dan sebagainya. Dalam penelitian ini hanya akan di analisa mengenai permasalahan penerapan prinsip syariah di dalam asuransi.

Beberapa prinsip syariah yang dapat diterapkan di dalam asuransi sebenarnya tidak jauh dengan prinsip syariah di lembaga keuangan syariah lainnya, prinsip tersebut antara lain Tidak mencari rizki pada hal yang haram, baik dari segi zatnya maupun cara mendapatkannya, serta tidak menggunakan untuk hal - hal yang haram, Tidak mendzalimi dan tidak didzalimi, Keadilan pendistribusian kemakmuran, Transaksi dilakukan atas dasar ridha sama ridha, Tidak ada unsur riba, Maysir (judi/spekulasi), dan Gharar (ketidak pastian/samar-samar). Dengan prinsip-prinsip tersebut, asuransi dapat di jalankan sesuai dengan syariah islam.

\section{METODE PENELITIAN}

Metode penelitian yang digunakan dalam penelitian ini adalah Metode diskriptif dengan menggunakan sumber data yang digunakan adalah data sekunder, yaitu pengumpulan data melalui studi literatur atau pustaka dari jurnal, buku, dan situs web site yang relevan

\section{HASIL DAN PEMBAHASAN}

\section{Penelitian terdahulu}

Beberapa penelitian yang telah dilakukan untuk menganalisa Asuransi Syariah diantaranya

Erza Armaz Hardi, judul penelitian "Studi komparatif Takaful dan Asuransi Konvensional". Dalam penelitiannya tersebut, peneliti berupaya membandingkan antara asuransi takaful dengan asuransi konvensional. Dalam pelaksanaannya asuransi syariah atau takaful menjalankan sepenuhnya prinsip syariah, sedangkan asuransi konvensional masih banyak terdapat sifat-sifat gharar, maisir, dan riba, sehingga dalam pelaksanannya asuransi konvensional masih jauh dari praktik syariah. Penelitian ini memiliki hasil penelitiaan yang dapat menarik bagi peneliti lain untuk melanjutkan penelitian dengan obyek penelitian tentang analisa prinsip syariah dalam asuransi. Sehingga dapat dihasilkan penelitian yang melengkapi penelitian sebelumnya.

Tazkiah Ashfia, Sihabudin, Prayudo Eri Yandono, Analisis Pengaturan Akad Tabarru' dan Akad Tijarah Pada Asuransi Syariah Menurut Fatwa DSN Nomor 21/ DSN-MUI/X/2001 Tentang Pedoman Umum Asuransi Syariah, dalam penelitian tersebut, dalam penelitian tersebut peneliti berupaya membahas tentang akad dalam asuransi 
syariah, yaitu akad tabrru dan akad tijarah berdasarkan fatwa DSN Nomor 21/DSNMUI/X/2001, hasil penelitian menunjukkan bahwa kedua akad tersebut terjadi keambiguan dalam memahami kedua ketentuan tersebut, oleh karena itu diperlukan dimasukkan frase terkait subjek yang terlibat dalam dua ketentuan tersebut agar lebih jelas. Penelitian ini menarik untuk menjadi sumber pembahasan bagi penelitian selanjutnya yang menganalisa prinsip-prinsip syariah dalam asuransi, dikarenakan untuk pemahaman kedua akad tersebut ternyata masih memiliki keambiguan dalam pemahaman.

Sri Wahyuni, Ramdan Asep Hidayar, Neneng Nurhasanah, Analisa Prinsip Syariah Terhadap Pelaksanaan Perjanjian Asuransi Jiwa Di PT. Asuransi Takaful Keluarga Cabang Bandung, dalam penelitian tersebut peneliti berupaya menganalisa pelaksanaan perjanjian asuransi jiwa di PT. Takaful keluarga Cabang Bandung berdasarkan prinsip syariah. Hasil penelitian ini menunjukkan bahwa perjanjian asuransi jiwa yang dilaksanakan oleh PT Takaful keluarga bandung, belum sepenuhnya menerapkan prinsip syariah, dari ketujuh prinsip tersebut baru lima prinsip yang dijalankan, dua prinsip lainnya belum dilaksanakan dengan baik. Dari hasil penelitian tersebut, menarik untuk dilakukan penelitian lanjutan yang menganalisa prinsip syariah dalam pelaksanaan asuransi syariah yang lebih luas, tidak hanya terbatas pada pelaksanaan perjanjian asuransi.

\section{Asuransi Konvensional}

Terdapat banyak pengertian asuransi yang dapat kita mengerti, diantaranya menurut Undang - undang no. 2 tahun 1992, yang dimaksud dengan asuransi adalah perjanjian antara dua belah pihak atau lebih, dengan mana pihak penanggung mengikatkan diri kepada tertanggung, dengan menerima premi asuransi, untuk memberikan penggantian kepada tertanggung karena kerugian, kerusakan, atau kehilangan keuntungan yang diharapkan, atau tanggung jawab hukum kepada pihak ke tiga yang mungkin akan di derita tertanggung, yang timbul dari suatu peristiwa yang tidak pasti, atau untuk memberikan suatu pembayaran yang didasarkan atas meninggal atau hidupnya seseorang yang dipertanggungkan. (UU No. 2, tahun 1992).

Selain pengertian tersebut masih terdapat pengertian lainnya yang pada dasarnya menyampaikan bahwa asuransi adalah kontrak pertanggungan antara tertanggung dengan penanggung (perusahaan asuranai) dimana pihak penanggung memiliki kewajiban memberikan ganti rugi kepada tertanggung apabila terkena musibah. Perjanjian ini mewajibkan tertanggung membayar premi setiap bulan kepada penanggung.

Terkumpulnya dana dari para tertanggung selain digunakan untuk membayar klim juga akan diinvestasikan oleh penanggung di investasi-investasi yang produktif. Dimana hasil investasi tersebut akan kembali kepada perusahaan setelah dikurangi biaya. Dalam asuransi konvensional selama ini dikenal dengan konsep pemindahan resiko (transfer of risk) dari peserta kepada peserta lain. Resiko dalam asuransi. konvensional di bagi menjadi tiga yaitu resiko murni, spekulatif dan induvidu. Dengan kata lain bahwa besaran premi yang harus dibayar oleh seorang pemegang asuransi di lihat dari besar kecilnya resiko yang di tanggung oleh perusahaan (Kasmir, 2014 : 264), Dalam asuransi konvensional, setiap tertanggung wajib membayar premi setiap bulannya, dan apabila tidak ada klaim maka preni tersebut hangus. Selain itu premi yang diinvestasikan oleh perusahaan, hasil investasi tidak akan dibagikan kepada tertanggung. Adapun prinsip asuransi konvensional menurut Joko Tri Haryanto baik asuransi umum atau asuransi jiwa adalah sebagai berikut: pertama, kepentingan yang dipertanggungkan (InsurableInterest). Kedua, kejujuran sempurna (Utmost Good Faith). Ketiga, Indemnitas (Indemnity). Ketiga, subrogasi (Subrogation). Keempat, Kontribusi (Contribution). Kelima, kausa proksimal (Proximate Cause). (Eja Armaz Hardi, 2015 : 427-428 ).

Dengan demikian terdapat beberapa praktik asuransi yang bertentangan dengan syariah Islam, diantaranya aspek riba, Menurut Syeikh Yusuf Al- Qardhawi asuransi konvensional itu sama dengan judi, karena tertanggung mengharapkan harta jaminan atau tanggungan melebihi jumlah pembayaran 
preminya. Oleh sebab itu, dalam asuransi tersebut juga ada unsur ribanya (Syakir, 2004 : 299). Selain riba unsur gharar, dan maisir. Masih banyak terjadi pada asuransi konvensional.

\section{Asuransi Syariah}

Definisi asuransi syariah menurut fatwa DSN adalah usaha saling melindungi dan tolong menolong diantara sejumlah orang atau pihak melalui investasi dalam bentuk aset atau tabbaru yang memberikan pola pengembalian untuk menghadapi resiko tertentu melalui akad atau perikatan yang sesuai dengan syariah. Definisi ini memberikan pengertian bahwa asuransi syariah dijalankan berdasarkan sifat saling menolong dan melindungi. Selain itu asuransi syariah memiliki istilah yang lain yaitu takaful yang berasal dari kata kafala yang berarti menanggung, menjamin. Sedangkan definisi lainnya menyebutkan Asuransi syariah adalah suatu pengaturan pengelolaan risiko yang memenuhi ketentuan syariah, tolongmenolong secara mutual yang melibatkan peserta dan operator. Syariah berasal dari ketentuan-ketentuan di dalam Al-Quran (firman Allah yang disampaikan kepada Nabi Muhammad saw) dan As-Sunnah (teladan dari kehidupan Nabi Muhammad SAW. (Muhaimin Iqbal, $2005: 2$ )

Oleh sebab itu, premi pada Asuransi Syariah adalah sejumlah dana yang dibayarkan oleh peserta yang terdiri atas Dana Tabungan dan Tabarru. Dana Tabungan adalah dana titipan dari peserta Asuransi Syariah (life insurance) dan akan mendapat alokasi bagi hasil (al-mudharabah) dari pendapatan investasi bersih yang diperoleh setiap tahun. Sedangkan, Tabarru' adalah derma atau dana kebajikan yang diberikan dan diikhlaskan oleh peserta asuransi jika sewaktu-waktu akan dipergunakan untuk membayar klaim atau manfaat asuransi (life maupun general insurance). (Syakir Sula, 2004 : 30).

Sebenarnya konsep asuransi Islam sudah diterapkan pada Zaman Rasulullah yang disebut dengan Aqilah. Menurut Thomas Patrick dalam bukunya Dictionary of Islam, hal ini sudah menjadi kebiasaan suku Arab sejak zaman dulu, jika ada salah satu anggota suku yang terbunuh oleh anggota dari suku lain, pewaris korban akan dibayar sejumlah uang darah (diyat) sebagai kompensasi oleh saudara terdekat dari pembunuh. Saudara terdekat pembunuh tersebut disebut Aqilah, harus membayar uang darah atas nama pembunuh. (Syakir Sula, 2004 : 30 - 31).

Beberapa ayat di dalam Al Qur'an sering menjadi dasar dalam menjalankan Asuransi syariah, ayat-ayat $\mathrm{Al}$ Qur' an tersebut diantaranya adalah : (Muhamad Thoin, Anik, 2015 : 4-6)

\section{Surat Al Maidah Ayat 2, yang artinya}

“....tolong-menolonglah kamu dalam (mengerjakan) kebaikan dan takwa, dan jangan tolong-menolong dalam berbuat dosa dan pelanggaran. Dan bertakwalah kamu kepada Allah, sesungguhnya Allah amat berat siksanya". (Q.S, Al-Maidah 5:2)

\section{Surat Al Baqarah Ayat 185, yang artinya}

"...Allah menghendaki kemudahan bagimu, dan tidak menghendaki kesukaran bagimu...." (Q.S. Al Baqarah 2 : 185)

\section{Surat Al Taghaabun Ayat 11}

“...tidak ada suatu musibah pun yang menimpa seseorang kecuali dengan izin Allah...." (Q.S, Al- Taghaabun 64 : 11).

\section{Surat Hud Ayat 16, yang artinya}

"Dan tidak ada suatu binatang melata pun di bumi melainkan Allah-lah yang memberi rezekinya." (Q.S, Hud, 11:16)

\section{Surat An Naml ayat 64, yang artinya :}

“...dan siapa (pula) yang memberikan rezeki kepadamu dari langit dan bumi ? apakah disamping Allah ada tuhan yang lain ?..." (Q.S, An-Naml. 27:64)

\section{Surat Al Hijr ayat 20, yang artinya :}

"dan kami telah menjadikan untukmu dibumi keperluan-keperluan hidup, dan (kami menciptakan pula) makhluk-makhluk yang kamu sekali-kali bukan memberi rezeki kepadanya." (Q.S, Al-Hijr, 15:20)

Dan masih ada beberapa ayat lainnya yang memberikan penjelasan tentang ketentuan-ketentuan hidup yang dapat 
menjadi pedoman bagi kita. Semua ayat itu membicarakan tentang ekonomi dimasa depan yang penuh kedamaian, yang selalu dibayangkan Islam. Dan seperti yang dinyatakan dalam Islam bahwa manusia sebagai Khalifah Allah di Bumi, hanya dapat mempertahankan gelarnya yang agung bila ia melaksanakan perintah perintah yang terkandung dalam Al-Qur'an dengan penafsiran yang tepat. Allah menghendaki tiadanya orang yang kehilangan mata pencaharianya yang layak, dan ia harus kebal terhadap setiap gangguan apapun. Oleh karena itu adalah kewajiban tertinggi dari suatu negara untuk menjamin hal ini. Dan asuransi membantu tercapainya tujuan ini. (AM Hasan Ali, 2004 : 105 - 110 )

Dengan adanya asuransi Syariah maka kebutuhan manusia akan jaminan kehidupan yang lebih baik akan terpenuhi, karena pada kenyataanya ciri khas asuransi adalah pembayaran dari semua peserta untuk membantu tiap peserta lainnya bila dibutuhkan. Prinsip saling menguntungkan ini tidak terbatas dalam kadar paling ringan bagi perusahaan bersama tapi berlaku juga untuk semua organisasi asuransi mana pun walau bgai mana pun struktur hukumnya. (Muhamad Abdul Manan, 301-302)

\section{Pandangan Ulama tentang Asuransi}

Munculnya Asuransi Syariah terjadi belum lama in, pada tahun tahun sebelumnya masih banyak pratik asuransi umum atau konvensional. Oleh karena itu Beberapa orang ulama, memberikan pandangan atau pendapatnya tentang asuransi, pendapat atau pandangan tersebut diantaranya : (Muhamad Thoin, Anik, 2015 : 7 - 8 ).

Ulama yang berpendapat asuransi dalam segala aspeknya haram termasuk asuransi jiwa. Pendapat ini didukung oleh kalangan ulama seperti Sayid Sabiq, Abdullah al-Qalqii, Muhammad Yusuf Qordawi dan Muhammad Bakhit al- Muth'i. Adapun alasan-alasan mereka mengharamkan asuransi antara lain : Pada dasarnya asuransi itu sama atau serupa dengan judi

Asuransi mengandung ketidakpastian

Asuransi mengandung riba
Asuransi bersifat eksploitas karena premi yang dibayarkan oleh peserta, jika tidak sanggup melanjutkan perjanjian maka premi hangus/ hilang atau dikurangi secara tidak adil ( peserta dizalimi )

Premi yang diterima oleh perusahaan diputar atau ditanam pada investasi yang mengandung riba / bunga

Asuransi termasuk akad sharfi, artinya jual beli atau tukar menukar uang dengan tidak tunai. Asuransi menjadikan hidup atau mati seseorang sebagai objek bisnis, yang berarti mendahului takdir Allah

Ulama yang berpendapat membolehkan asuransi termasuk asuransi jiwa dalam prakteknya sekarang. Pendapat ini didukung oleh ulama seperti Abdul Wahab Khallaf, Mustafa Ahmad Zarqa, Muhammad Yusuf Musa dan Abdurrahman isa. Alasan mereka memperbolehkannya adalah:

Tidak ada nas Al Quran dan Hadis yang melarang asuransi

Ada kesepakatan antara kedua belah pihak Mengandung kepentingan umum (maslahah), sebab premi-premi yang terkumpul bisa diinvestasikan untuk proyek- proyekyang produktif dan untuk pembangunan

Asuransi termasuk akad mudharabah, artinya akad kerja sama bagi hasil antara pemegang polis (pemilik modal) dengan pihak perusahaan asuransi yang memutar modal atas dasar profit and loss sharin

Asuransi termusak koperasi (syirkah ta'awwuniah)

Diqiyaskan (analogi) dengan system pension

Pendapatan kedua ini menitikberatkan pada jenis asuransi sosial dan koperasi yang dikelolaoleh pemerintah, bertujuan bukan komersial, melainkan lebih pada kemaslahatan umat seperti taspen, Jasa Raharja, dan lain sebagainya.

Ulama yang berpendapat bahwa asuransi bersifat syuhbat beralasan karena tidak ada dalil-dalil syar'i yang secara jelas mengharamkan atau menghalalkannya. Bila hukum asuransi dimasukkan dalam hal syubhat, maka kita harus berhati-hati menghadapinya. Kita baru diperbolehkan menggunakan asuransi kalau dalam keadaan 
darurat dan sangat dibutuhkan. Untuk saat ini setelah munculnya asuransi syariah, maka tidak ada lagi istilah syubhat.

\section{Prinsip - Prinsip dalam Asuransi Syariah}

Secara umum asuransi Syariah sangat berbeda dengan asuransi konvensional. Asuransi Syariah dijalankan berdasarkan niat untuk saling menolong, membantu terhadap sesama peserta. Sesuai dengan perintah agama. Oleh karena itu prinsip - prinsip dalam asuransi Syariah sesuai dengan Agama islam. Prinsip-prinsip tersebut antara lain, (Syakir Sula, 2004 : 722 - 750)

\section{Tauhid (Ketaqwaan)}

Pada prinsip ini asuransi syariah dijalankan dengan dasar muamalah yang telah ditentukan oleh Allah SWT, yaitu muamalah yang dapat membawa umat manusia kepada ketaqwaan kepada AllahSWT. Oleh karena itu firman Allah di dalam surat Az Zukhruf : 32, yang artinya “Apakah mereka yang membagi-bagi rahmat Tuhanmu? Kami telah menentukan antara mereka penghidupan mereka dalam kehidupan dunia, dan Kami telah meninggikan sebahagian mereka atas sebagian yang lain beberapa derajat, agar sebagian mereka dapat mempergunakan sebagian yang lain. dan rahmat Tuhanmu lebih baik dari apa yang mereka kumpulkan" menjadi dasar dijalankannya asuransi syariah. Muamalah yang dibangun dalam asuransi syariah hendaknya berlandaskan pada surat tersebut. Dengan demikian niat dalam asuransi syariah hendaklah tidak hanya untuk berinvestasi memperoleh keuntungan, akan tetapi lebih luas lagi yaitu memperoleh pahala dari Allah SWT, dengan muamalah yang sesuai ketentuan Allah.

\section{Al - Adl (sikap adil)}

Cukuplah bagi kita bahwa Al-quran telah menjadikan tujuan semua risalah langit adalah melaksanakan keadilan. (Syakir Sula, 2005 : 727) Syaikh al-Qaradhawi mengatakan bahwa sesungguhnya pilar penyanggah kebebasan ekonomi yang berdiri diatas kemuliaan fitrah dan harkat manusia disempurnakan dan ditentukan oleh pilar penyangga yang lain, yaitu "keadilan". Keadilan dalam islam bukanlah prinsip sekunder. Ia adalah cikal bakal dan fondasi kokoh yang melandasi semua ajaran dan hukum islam berupa akidah, syariah, dan akhlak (moral). Ketika Allah memerintahkan tiga hal, maka keadilan merupakan hal pertama yang disebutkan. Dalam firman Allah:"Sesungguhnya Allah menyuruh (kamu) Berlaku adil dan berbuat kebajikan, memberi kepada kaum kerabat, dan Allah melarang dari perbuatan keji, kemungkaran dan permusuhan. Dia memberi pengajaran kepadamu agar kamu dapat mengambil pelajaran." (An-Nahl: 90). Dalam prinsip keadilan ini, Asuransi Syariah telah memberikan keadilan yang sebenarnya, yaitu dengan memberikan kemudahan bagi peserta asuransi untuk mengumpulkan dana dan mengembalikan dana itu kembali jika peserta mengakhiri perjanjian dalam asuransi.

\section{Asz-Dzulm (Kedzaliman)}

Pelanggaran terhadap kedzaliman merupakan salah satu prinsip dasar dalam muamalah. Kedzaliman adalah kebalikan dari sikap keadilan. Karena itu, islam sangat ketat dalam memberikan perhatian terhadap pelanggaran kedzaliman, penegakan larangan terhadapnya, kecaman keras terhadap orangorang yang dzalim, ancaman terhadap mereka dengan siksa yang paling keras di dunia dan akhirat. Dalam prinsip ini, asuransi syariah dijalankan dengan memperhatikan keuntungan yang diperoleh oleh para peserta, dengan demikian setiap produk asuransi syariah harus memberikan keuntungan sebesar - besarnya bagi kesejahteraan peserta.

\section{At Taawun (tolong menolong)}

Al Maidah ayat 2, yang artinya : “...tolong-menolonglah kamu dalam (mengerjakan) kebaikan dan takwa, dan jangan tolong-menolong dalam berbuat dosa dan pelanggaran. Dan bertakwalah kamu kepada Allah, sesungguhnya Allah amat berat siksanya". (Q.S, Al-Maidah 5:2). Menjadi dasar dalam Asuransi Syariah. Beberapa perusahaan asuransi syariah yang memiliki produk asuransi syariah telah menerapkan prinsip tolong menolong ini dengan baik. Setiap peserta yang mengambil produk asuransi syariah akan membantu peserta lain ketika mereka membutuhkan dana untuk kesehatan, kecelakaan ataupun kerugian lainnya. Dengan 
prinsip ini maka di Asuransi Syariah setiap dana peserta akan ditampung dan digunakan untuk membantu peserta lain, apabila peserta tersebut berhenti dari program asuransi, maka dana tersebut dapat diambil kembali.

\section{Amanah (terpercaya)}

Al-Qaradhawi mengatakan bahwa diantara nilai transaksi yang terpenting dalam bisnis adalah al-amanah 'kejujuran'. Ia merupakan puncak moralitas iman dan karakteristik yang paling menonjol dari orang-orang yang beriman. Bahkan, kejujuran merupakan karakteristik para nabi. Tanpa kejujuran, kehidupan agama tidak akan berdiri tegak dan kehidupan didunia tidak akan berjalan baik. Dalam praktik asuransi syariah, kejujuran tersebut di wujudkan dalam bentuk pengelolaan dana yang transparan, yang dapat di ikuti oleh setiap peserta. Perusahaan asuransi syariah akan memberikan laporan pengelolaan dana kepada para peserta.

\section{Ridha}

Firman Allah,"Hai orang-orang yang beriman, janganlah kamu saling memakan harta sesamamu kecuali denganjalan perniagaanyang berlaku dengan suka sama suka diantara kamu." Abul A'la al-Maududi dalam kitabnya menjelaskan ayat diatas menurutnya, ayat ini telah menetapkan dua perkara sebagai syarat bagi sah nya perdagangan. Pertama, hendaknya perdagangan itu dilakukan dengan suka sama suka diantara dua belahh pihak, tidak berdiri diatas kerugian pihak lain.Keridhaan dalam muamalah merupakan syarat sahnya akad antara kedua belah pihak, sedangkan mengetahui adalah syarat sah ridha. Faktor mengetahui menjadi syarat sah nya ridha, agar dalam transaksi tersebut tidak terjadi gharar. (Syakir Sula, 2004 : 742)

\section{Khitmah (Pelayanan)}

Rasulullah bersabda," seorang iman (pemimpin) adalah pemelihara dan mengatur urusan (rakyat). Ia akan diminta pertanggungjawaban atas urusan rakyatnya." ( HR. Bukhari dan Muslim). "dan berendah dirilah kamu terhadap orangorang yang beriman." (QS. Al-Hijr: 88). Yang dimaksud dengan pelayanan tersebut adalah asuransi syariah memperhatikan kepentingan peserta nya dengan baik. Setiap kepentingan peserta asuransi yang berkaitan dengan klaim, investasi dana peserta, dan pengumpulan dana peserta (tabarru) akan mendapatkan pelayanan dari perusahaan asuransi syariah dengan baik dan transparan. Dengan kemudahan ini diharapkan peserta asuransi syariah akan lebih nyaman dan aman terhadap dana kepesertaannya.

\section{Gharar, Maisir, Dan Riba}

Prinsip yang paling utama dalam muamalah Islami khususnya untuk Lembaga Keuangan Syariah (LKS) adalah prinsip Gharar, Maisir dan Riba. Ketiga hal inilah yang secara haqiqi menjadi dasar para ulama mengharamkan semua transaksi perbankan, asuransi, penggadaian, bursa efek, leasing, modal ventura dan sebagainya, yang tidak menggunakan prinsip-prinsip syariah. Karena, dalam operasionalnya pasti terdapat salah satu atau kalau tidak tiga-tiganya yang Gharah, Meisir atau Riba. (Syakir Sula, 2004 : 750 ). Produk asuransi syariah telah dijamin bebas dari unsur Gharar, maisir, dan riba. Dikarenakan (Syakir Sula, 2004 : 293 - 319)

Asuransi syariah kegiatannya diawasi oleh DSN (Dewan Syariah Nasional), berfungsi untuk mengawasi semua operasional atau kegiatan perusahaan agar terbebas dari praktik - praktik muamalah yang bertentangan dengan prinsip syariah

Semua akad asuransi telah menggunakan akad syariah, misalnya Mudharabah, Ijarah, wakalah, wadiah, dan sebagainya.

Terdapat pemisahan antara dana tabarru' dengan dana perusahaan, sehingga tidak mengenal istilah dana hangus.

Dana yang terkumpul dari peserta dalam bentuk iuran atau kontribusi tetap menjadi milik peserta, perusahaan atau entitas asuransi syariah hanya sebagai pemegang amanah dalam mengelola dana tersebut.

Dapat melakukan investasi sesuai ketentuan perundang undangan, sepanjang tidak bertentangan dengan prinsip prinsip syariah Islam. Bebas dari riba dan tempat investasi yang terlarang.

Sumber pembayaran klaim diperoleh dari rekening tabarru', peserta saling menanggung. 
Jika salah satu peserta mendapat musibah, maka peserta lainya ikut menanggung bersama risiko tersebut.

Keuntungan diperoleh dari surplus underwriting, komisi reasuransi, dan hasil investasi bukan seluruhnya menjadi milik perusahaan tetapi dilakukan bagi hasil dengan peserta.

Dalam operasionalny asuransi syariah telah banyak melaksanakan ketentuan syariah tersebut diatas dengan baik,entitas asuransi syariah menjalankan usahanya dengan transparan dan mengelolanya sesuai dengan syariah islam.

\section{KESIMPULAN}

Sistem Ekonomi Islam memiliki karakteristik yang berbeda dengan ekonomi konvensional. Ekonomi Islam merupakan sistem yang adil dan seksama serta berupaya menjamin kekayaan tidak terkumpul hanya kepada satu kelompok saja, tetapi tersebar ke seluruh masyarakat.

Dengan ajaran yang seimbang tersebut, maka Islam menganjurkan bahwa setiap kegiatan investasi harus memperhatikan prinsip-prinsip yang ada didalam agama Islam. Salah satu kegiatan investasi yang harus memperhatikan nilai-nilai Islam tersebut adalah Asuransi. Didalam asuransi yang diinvestasikan adalah jaminan yang diberikan penanggung (perusahaan asuransi) kepada yang tertanggung untuk resiko kerugian yang telah ditetapkan di dalam perjanjian (polis) bila terjadi kebakaran, sakit, kecurian, kerusakan atau kehilangan jiwa, dengan kewajiban tertanggung membayar premi setiap bulannya.

Menurut Undang-undang no. 2 tahun 1992, yang dimaksud dengan asuransi adalah perjanjian antara dua belah pihak atau lebih, dengan mana pihak penanggung mengikatkan diri kepada tertanggung, dengan menerima premi asuransi, untuk memberikan penggantian kepada tertanggung karena kerugian, kerusakan, atau kehilangan keuntungan yang diharapkan, atau tanggung jawab hukum kepada pihak ke tiga yang mungkin akan di derita tertanggung, yang timbul dari suatu peristiwa yang tidak pasti, atau untuk memberikan suatu pembayaran yang didasarkan atas meninggal atau hidupnya seseorang yang dipertanggungkan.

Definisi asuransi syariah menurut fatwa DSN (Dewan Syariah Nasional) adalah usaha saling melindungi dan tolong menolong diantara sejumlah orang atau pihak melalui investasi dalam bentuk aset atau tabbaru yang memberikan pola pengembalian untuk menghadapi resiko tertentu melalui akad atau perikatan yang sesuai dengan syariah.

Prinsip yang dijalankan dalam asuransi syariah adalah Tauhid (Ketaqwaan), Keadilan, Tidak Dzalim, At Tawaun (tolong menolong), Amanah, Ridha, Khitmah (pelayanan yang baik), dan terbebas dari unsur gharar, maisir, dan riba.

Ketujuh prinsip asuransi tersebut, telah dijalankan dengan baik oleh entitas asuransi, hal ini terbukti dari pelaksanaan akan asuransi yang telah dijalankan dengan kesepakatan kedua belah pihak, serta pengelolaan dana asuransi dari para peserta telah sesuai dengan prinsip syariah.

Dalam pelaksanaannya banyak entitas asuransi syariah telah menjalankan prinsip syariah dengan baik walaupun masih terdapat beberapa kekurangan dalam asuransi syariah, misalnya dalam penelitian yang telah dilakukan oleh Erza Armas hardi, 2015 diperoleh hasil bahwa asuransi syariah belum menyentuh kelompok masyarakat paling bawah (grass root).

Diperlukan pemikiran lebih lanjut, bahwa akad tabbaru yang merupakan hibah kemungkinan dapat diganti dengan akad wadiah atau titipan. Sehingga akad wadiah dapat memperjelas status dana peserta sebagai dana titipan, bukan hibah kepada entitas asuransi syariah. (Tazkia Ashifa, dkk)

\section{DAFTAR PUSTAKA}

Nur Hidayati Rosidah, Asuransi Konvensional dan Asuransi Syariah : Perbedaan Dalam Lingkup Akuntansi, Universitas negeri Surabaya, Universitas Surabaya, Surabaya. Kitab Undang-Undang Hukum Dagang, Citra Umbara, bandung, 2010

Eja Armaz Hardi, Studi Komparatif Takaful Dan Asuransi Konvensional, Jurnal Bisnis Dan Manajemen, Vol. 3 no. 2, Desember 2015. 
Bappepam-LK, Laporan Tahunan 2010, Kementrian Keuangan RI, Jakarta, 2010. Bappepam-LK, Laporan Tahunan 2011, Kementrian Keuangan RI, Jakarta, 2011.

Fatwa Dewan Syariah Nasional. No. 21/DSNMUI/X/2001. Tentang Pedoman Umum Asuransi Syariah.

Kaslan. A. Tohir. "Ekonomi Modern". Pradnya Paramita. Jakarta. 1975.

Nurul Huda dan M. Haykal. Lembaga Keuangan Islam: Tinjauan Teoritis dan Praktis. h. 2010.

Sri Wahyuni, Asep Ramdan Hidayat, Neneng Nurhasanah, Analisa Pelaksanaan prinsip Asuransi Syariah Terhadap Pelaksanaan Perjanjian Asuransi jiwa Di PT. Asuransi Takaful Keluarga Cabang Bandung, Keuangan dan Perbankan Syariah, Fakultas Syariah, Universitas Islam Bandung,

Undang-undang no. 2 Tahun 1992 tentang usaha perasuransian.

Kasmir. Bank dan Lembaga Keuangan Lainnya. Rajawali Pers. Jakarta. Ed Revisi. 2014.

Muhammad Syakir Sula, Asuransi Syariah: Life and general: Konsep dan Sistem Operasional, Gema Insani Press, Jakarta, 2004, cet-1.

Muhamad Thoin, Anik, Aspek-Aspek Syariah Dalam Asuransi Syariah, Jurnal Ekonomi Islam Vol. 1, No. 1, Maret 2015, STIE AAS Surakarta.
Muhaimin Iqbal, Asuransi Umum Syariah Dalam Praktik (Upaya menghilangkan Gharar, Maisir, Riba), Gema Insani Pres, Jakarta, 2005.

AM. Hasan Ali, Asuransi Dalam Perspektif hukum Islam, Jakarta, Prenada Media, 2004

Tazkiah Ashfia, Sihabudin, Prayudo Eri Yandono, Analisis Pengaturan Akad Tabarru' dan Akad Tijarah Pada Asuransi Syariah Menurut Fatwa DSN Nomor 21/ DSN-MUI/X/2001 Tentang Pedoman Umum Asuransi Syariah, Universitas Brawijaya, malang.

Kasmir. Bank dan Lembaga Keuangan Lainnya. Rajawali Pers. Jakarta. Ed Revisi. 2014.

Yadi jawari, Asuransi Syariah, Pustaka Bani Quraiy, Bandung, 2005.

Anwar, Khoiril.. Asuransi Syariah, Halal dan Maslahat. Solo: Penerbit Tiga Serangkai, 2007

h t t p: / / fin a n sial.bis nis.com / $\mathrm{read} / 20170830 / 215 / 685502 /$ aset-industriasuransi-syariah-juli-2017-tumbuh-1726, selasa 12 Desember 2017, jam 09.45

http:/ / www.republika.co.id/berita / ekonomi/syariah-ekonomi/17/08/30/ ovg6vn416-kontribusi-asuransi-syariahtumbuh-346-persen, selasa 12 Desember 2017, jam 09.45 